\title{
The effect of arabinoxylanase and protease supplementation on nutritional value of diets containing wheat bran or rice bran in growing pig*
}

\author{
Y.-L. Yin ${ }^{1,2,1}$, Z.-Y. Deng ${ }^{1,2}$, H.-L. Huang' ${ }^{2}$ T.J. Li ${ }^{2}$ and H.-Y. Zhong ${ }^{2}$ \\ ${ }^{1}$ Department of Food Science and Engineering, Nanchang University \\ Nanchang 330047, P.R. China \\ ${ }^{2}$ Key Laboratory of Subtropical Agro-ecology, Institute of Subtropical Agriculture, \\ The Chinese Academy of Sciences \\ Changsha, P.O. Box 10, Hunan 410125, P.R. China
}

(Received 20 January 2003; revised version 31 May 2004; accepted 16 June 2004)

\begin{abstract}
One digestibility and one performance experiments were conducted to investigate the effects of a feed enzyme of arabinoxylanase and arabinoxylanase plus protease on digestibility of nutrients, nitrogen $(\mathrm{N})$ flow and performance of the growing pigs fed a maize-wheat bran-based diet or a maize-rice bran-based diet. In the digestion experiment, six Landrace $\times$ Large White $\times$ Chinese Black male pigs of approximately $20 \mathrm{~kg}$ initial body weight, fitted with a simple T-cannula at the terminal ileum, were used to study dietary nutrient digestibility and nitrogen flow of the experimental diets. The six experimental diets were prepared in this study: maize-wheat bran diet, consists of maize, wheat bran, soyabean, of rapeseed meal, without feed enzyme supplementation (MWB); MWB supplemented with arabinoxylanase (A); MWB supplemented with arabinoxylanase plus protease (AP); maize-rice bran diet, consists of maize, rice bran, soyabean, rapeseed meal, without feed enzyme supplementation (MRB); MRB supplemented with arabinoxylanase (A); MRB supplemented with arabinoxylanase plus protease (AP). The MWB diet contained: \%: soluble nonstrach polysaccharide (NSP) 0.8 , insoluble NSP 19, crude protein 22, and $18.6 \mathrm{MJ} / \mathrm{kg}$ gross energy (GE), while the MRB diet contained, \%, respectively: 0.5 , 22, 21, and $18.9 \mathrm{MJ} / \mathrm{kg} \mathrm{GE}$. In the performance experiment, lasting 40 days, 60 pigs (30 gilts and 30 castrates) with body weight of $20.5 \pm 0.76 \mathrm{~kg}$ were randomly allocated to the six dietary treatments with a completely randomized design (5 gilts and 5 castrates per treatment). Feed and water were provided ad libitum.
\end{abstract}

\footnotetext{
"Supported by National Natural Science Foundation of China, NSFC 30371038, and The Chinese Academy of Science, Project No. KSCX2-SW-323

${ }^{3}$ Corresponding author: Yulong Yin, Institute of Subtropical Agriculture, the Chinese Academy of Sciences, Changsha, Hunan 410125, P.O.Box 10, P.R. China; e-mail: yyulong2003@yahoo.com.cn
} 
The results show there were no significant differences in average daily gain (ADG) $(\mathrm{P}=0.09)$, feed gain ratio $(\mathrm{F} / \mathrm{G} ; \mathrm{P}=0.09)$, ileal digestibility of nutrients $(\mathrm{P}=0.09)$ and $\mathrm{N}$ flow $(\mathrm{P}>0.08)$ between the MWB and MRB diet, although the crude fibre level in the MRB diet had higher crude fibre content $(9.7 \mathrm{~g} / \mathrm{kg})$ than that the MWB diet. The dry matter intake (DMI) of the MWB diet was increased $(\mathrm{P}<0.05)$ by the enzyme A supplementation. The ADG and $F / G$ of the pigs fed the MWB diet were improved $(\mathrm{P}<0.05)$ by either arabinoxylanase or arabinoxylanase plus protease supplementation. The ileal endogenous $\mathrm{N}$ excretion determined with enzymatic hydrolysed casein diet in this experiment was half higher than that calculated from the $\mathrm{N}$-free diet. The ileal digestibility of soluble NSP fractions of the MWB and MRB diets were significantly $(\mathrm{P}<0.05)$ increased by either enzyme arabinoxylanase or arabinoxylanase plus protease supplementation. There was no enzyme effect on insoluble NSP fraction digestibility. The results of this study suggest that NSP degrading enzyme do mainly reduce the negative nutritional effect of the soluble NSP in the small intestine of growing pigs.

KEY WORDS: pigs, enzymes, rice bran, wheat bran, digestion, performance

\section{INTRODUCTION}

Rice bran and wheat bran are both widely used in pig diets, especially in Asia, but digestibility and animal performance experiments have shown that inclusion of either of the bran reduces feed intake (Chen, 1981), decreases ileal and overall digestibility (Chen 1979; Graham et al., 1986), and results in poor growth rates (Hanrahan and O'Grady, 1970; Chen, 1981). Recent studies on the cereal shows that plant cell walls contain primarily complex carbohydrates referred to as nonstarch polysaccharides (NSP), which can negatively affect nutrient utilization (Englyst and Hudson, 1996). The NSP constituents of the endosperm cell walls of wheat and barley are mainly arabinoxylans and barley also contains high levels of B-glucans (Yin et al., 2000a,b,c; 2001a,b). Many studies have investigated ways of removing these polymers, which encapsulate the desired nutrients in the endosperm. However, feed processing techniques such as extrusion cooking, gamma irradiation, micronization and flaking did not significantly improve nutrient utilization (McClean, 1993).

Xylanase enzyme, in combination with $\beta$-glucanase has been reported to improve hulless barley apparent ileal digestibility of nutrients (Yin et al., 2000a; 2001a,b) and growth performance of young pigs (Baidoo et al., 1998). However, the effects of feed enzyme on nutrient utilization and nitrogen flow through the terminal ileum and excretion in faeces in growing pigs fed rice or wheat bran based diet were seldom reported in the literature. The objects of this study were to determine the effects of carbohydrase and protease supplementation of the maizerice bran and maize-wheat bran-based diets on apparent and true digestibility of nutrients, nitrogen flow and performance of growing pigs. 


\section{MATERIAL AND METHODS}

\section{Diets}

One butch of wheat bran and one butch of rice bran were used in this experiment. Six diets (Table 1) were prepared: maize-wheat bran diet without feed enzyme supplementation (MWB); MWB supplemented with arabinoxylanase (HuaFan Feed Company, Zhao Qing, Guangzhou, China) 1 g/kg diet (MWB+A); maizewheat bran-base diet supplemented with arabinoxylanase $(1 \mathrm{~g} / \mathrm{kg}$ diet $)$ plus protease (HuaFan Feed Company, Zhao Qing, Guangzhou, China) $0.2 \mathrm{~g} / \mathrm{kg} \operatorname{diet}$ (MWB+AP); MWB without feed enzyme supplementation (MRB); MRB supplemented with arabinoxylanase, $1 \mathrm{~g} / \mathrm{kg}$ diet (MRB+A); MRB supplemented with arabinoxylanase $(1 \mathrm{~g} / \mathrm{kg}$ diet $)$ plus protease $(0.2 \mathrm{~g} / \mathrm{kg}$ diet $)(\mathrm{MRB}+\mathrm{AP})$.

TABLE 1

Composition of experimental diets (maize-wheat bran based diet (MBW), that diet supplemented with arabinoxylanase $(\mathrm{MWB}+\mathrm{A})$ or with arabinoxylanase + protease $(\mathrm{MWB}+\mathrm{AP})$ and maize-rice bran diet (MRB), that diet supplemented with arabinoxylanase (MWB+A) and arabinoxylanase + protease (MWB +AP), g/kg

\begin{tabular}{lcccccc}
\hline Diet & MWB- & $\begin{array}{c}\text { MWB } \\
+\mathrm{A}\end{array}$ & $\begin{array}{c}\text { MWB } \\
+ \text { AP }\end{array}$ & MRB- & MRB+A & $\begin{array}{c}\text { MRB } \\
+ \text { AP }\end{array}$ \\
\hline Maize & 490.0 & 489.0 & 488.8 & 490.0 & 489.0 & 488.8 \\
Wheat bran & 262.0 & 262.0 & 262.0 & - & - & - \\
Soyabean meal & 208.7 & 208.7 & 208.7 & 208.7 & 208.7 & 208.7 \\
Rapeseed oil & 10.5 & 10.5 & 10.5 & 10.5 & 10.5 & 10.5 \\
Rice bran & - & - & - & 262.0 & 262.0 & 262.0 \\
L-lysine HCl & 1.70 & 1.70 & 1.70 & 1.70 & 1.70 & 1.70 \\
Salt & 3.5 & 3.5 & 3.5 & 3.5 & 3.5 & 3.5 \\
Limestone & 8.6 & 8.6 & 8.6 & 8.6 & 8.6 & 8.6 \\
Dicalcium phosphate & 12.5 & 12.5 & 12.5 & 12.5 & 12.5 & 12.5 \\
Mineral/vitamins ${ }^{1}$ & 2.5 & 2.5 & 2.5 & 2.5 & 2.5 & 2.5 \\
Arabinoxylanase & - & 1 & 1 & - & 1 & 1 \\
Protease & - & - & 0.2 & - & - & 0.2 \\
\hline
\end{tabular}

${ }^{1}$ supplying per kg diet: vit. A, 8000 IU; vit. $\mathrm{D}_{3}$, $2000 \mathrm{IU}$; $\mathrm{mg}$ : vit. E, 40; vit., $\mathrm{K}$ 1; vit. $\mathrm{B}_{2}$, 2; vit. $\mathrm{B}_{12}$, 0.012; $\mathrm{Cu}, 15$ (from CuSO4.5H $\mathrm{H}_{2}$ ); $\mathrm{Zn}, 100$ (from ZnO); Fe, 100 (from $\mathrm{FeSO}_{4} \cdot \mathrm{H}_{2} \mathrm{O}$ ); $\mathrm{Mn}, 20$ (from $\mathrm{MnO}) ; \mathrm{IO}_{3}$ (from $\left.\mathrm{Ca}\left(\mathrm{IO}_{3}\right)_{2}\right)$; $\mathrm{Se}, 0.3\left(\right.$ from $\mathrm{Na}_{2} \mathrm{SeO}_{3}$ )

\section{Experiment 1. Digestion experiment}

Animals and procedures. Six Large White $\times$ Landrace $\times$ Chinese Black barrows with an average initial body weight (BW) $21.0 \pm 0.9 \mathrm{~kg}$, were surgically fitted with a simple T-cannula at the distal ileum according to the procedure described by Sauer et al. (1983). The cannulas were modified according to de Lange et al. (1989). 
After surgery, the pigs were housed individually in stainless steel metabolic crates in a temperature-controlled barn $\left(20\right.$ to $\left.22^{\circ} \mathrm{C}\right)$. During a 13 -d recovery period, the pigs were fed a commercial starter diet containing $18 \%$ of protein.

The experiment was designed and conducted according to a $6 \times 6$ Latin square design. After recovering from surgery, the pigs were offered one of the 5 diets (Table 1, diet MRB + AP was excluded) at 08:00 and 18:00 daily as a wet mash. The sixth diet was of the enzyme hydrolysed casein (EHC) diet which was used for determination of the ileal endogenous nitrogen $(\mathrm{N})$ and amino acid (AA) flow. Chromic oxide was incorporated into all of the diets as an indigestible marker. The EHC diet was formulated with $\mathrm{g} / \mathrm{kg}$ of: enzyme hydrolysed casein 150, (MW >5000Da, New Zealand Pharmaceuticals Ltd. Palmerston North, New Zealand), rapeseed oil 35, cellulose 50, sucrose 70, maize starch 629 and chromic oxide 2 , and vitamin and mineral mixture 64 (for composition see Table 1). Pigs were fed at 2.6 times of their maintenance energy requirement (NRC, 1998) based on their BW at the beginning of each experimental period. Water was added to each meal in a 2:1 ratio. Additional water was available from a nipple drinker.

The experimental period lasted 14 days each. Pigs were allowed to adapt to their respective experimental diets for $7 \mathrm{~d}$ and then 3 days of faeces collection. On the $11^{\text {th }}$ day, ileal digesta samples were collected continuously for $24 \mathrm{~h}$ using plastic bags (length, $16 \mathrm{~cm}$; i.d., $10 \mathrm{~cm}$ ) attached to the cannula. The bag contained approximately $10 \mathrm{ml}$ of a formic acid solution $(10 \%, \mathrm{v} / \mathrm{v})$ to minimize further microbial activity. The bag was removed and replaced as soon as it was partially filled with digesta. Digesta were immediately frozen at $-20^{\circ} \mathrm{C}$ following collection.

\section{Experiment 2. Performance experiment}

Sixty Landrace $\times$ Large White $\times$ Chinese Black pigs ( 30 gilts and 30 barrows) with body weight of $20.5 \pm 0.76 \mathrm{~kg}$ were randomly allocated to the six dietary treatments (Table 1) with a completely randomised design ( 5 gilts and 5 barrows per treatment). The pigs were housed individually in floor pens $(1.2 \mathrm{~m} \times 1.3 \mathrm{~m})$ in an environmentally controlled room and at an environmental temperature of at least $18^{\circ} \mathrm{C}$. The pens were fitted with flooring made of plastic covered woven iron and stainless steel single-space feeders and nipple drinker; pen partitioning were made of metal bars. Feed and water were provided ad libitum.

Individual pig weights and pen feed intake were determined weekly. If feed was dry (not contaminated) the weight was recorded directly. If contamination had occurred the feed was dried and weighed for correction of feed intake. The experimental period lasted 40 days. 


\section{Chemical analysis}

After the conclusion of the animal trial, faeces and digesta were freeze-dried, pooled for each within animal and period, ground through a $1.00-\mathrm{mm}$ mesh screen, and mixed before analyses.

For the digesta collected from the EHC diet were thawed and pooled for each pig over the each collection periods. A sub-sample of approximately $100 \mathrm{~g}$ was taken from each digesta pool, and centrifuged at $7000 \mathrm{~g}$ for $11 \mathrm{~min}$. The supernatant fractions were than ultra filtered using Centriprep YM-10 (Amicon-Millipore, Beyerly, MA, USA; Cat. No. 4305, 10000 Da MM cut-off) according to the manufacture's instructions. The precipitate from the centrifugation step was added to the retentate from the ultra filtration, and the material freeze-dried and finely ground.

Dry matter $(\mathrm{DM})$, gross energy $(\mathrm{GE})$, crude protein $(\mathrm{CP}, \mathrm{N} \times 6.25$, macroKjeldahl), crude fibre and crude fat contents were determined according to AOAC (1990). Samples were also analysed for chromic oxide (Fenton and Fenton, 1979). Amino acid (AA) contents were determined by ion exchange chromatography following hydrolysis in $6 \mathrm{~N}$ hydrochloric acid at $110^{\circ} \mathrm{C}$ for $24 \mathrm{~h}$. Methionine and cysteine were determined as methionine sulphone and cysteic acid after oxidation with performic acid. Soluble and insoluble NSP sugars and uronic acids in diets were determined by gas chromatography (Pye Unicam 304) according to Englyst and Cummings (1984).

\section{Calculations and statistical analyses}

The apparent digestibility of energy, crude protein and AA were calculated as:

$$
\left.\mathrm{D}_{\mathrm{D}}(\%)=100-\left[\mathrm{I}_{\mathrm{D}} \times \mathrm{A}_{\mathrm{F}}\right) /\left(\mathrm{I}_{\mathrm{F}} \times \mathrm{A}_{\mathrm{D}}\right)\right] \times 100
$$

where $D_{D}$ is the apparent digestibility of a nutrient in the diet; $I_{D}$ is the marker concentration in the diet; $A_{F}$ is the nutrient concentration in faeces or ileal digesta; $I_{F}$ is the marker concentration in faeces or ileal digesta; and $A_{D}$ is the nutrient concentration in the diet. All variables were expressed in percentages.

The ileal true digestibility (TID) of CP and AA were calculated as:

$$
\operatorname{ITD}(\%)=100 \times\left(1-\left[\left(10 \times \mathrm{AA}_{\text {diet }}\right)-\left[\left(10 \times \mathrm{AA}_{\text {diet }}\right) \times\left(\mathrm{AA}_{\mathrm{AID}} / 100\right)\right]-\mathrm{AA}_{\mathrm{E}}\right) /\left(10 \times \mathrm{AA}_{\text {diet }}\right)\right]
$$

where $\mathrm{AA}_{\mathrm{E}}$ is the gut endogenous $\mathrm{AA}$ or $\mathrm{N}$ losses expressed as $\mathrm{g} / \mathrm{kg}$ dry matter intake determined with the EHC or protein free diet reported by CVB (1998) and the $\mathrm{AA}_{\mathrm{E}}$ was calculated as:

$\mathrm{AA}_{\mathrm{E}}=$ concentration of compound in digesta $\times$ diet $\mathrm{Cr}$ concentration/digesta Cr concentration. 
The results of the growth performance were analysed as a completely randomised design, with a $2 \times 3$ factorial treatment, in which animals were randomly assigned to the MWB or MRB diet, with or without enzyme A or enzyme B supplementation. Differences between means were compared using the Student-Neuman-Keuls (SNK) method at a significance level of $\mathrm{P}<0.05$. Data from the digestion trial were first subjected to analysis of variance (ANOVA). Sources of variation were diets $(n=6)$, periods $(n=6)$ and pigs $(n=6)$. Where appropriate, treatment means were compared using the Student-Newman Keuls' multiple range tests. The ANOVA, comparisons of means, and regression analyses were carried out using the General Linear Model Procedure of SAS Institute, Inc. (1988).

\section{RESULTS}

The proximate analysis of a number of chemical constituents of the wheat bran and rice bran diets, including AA is shown in Table 2. The CP and most AA were slightly higher for the wheat bran diet. Conversely, the crude fibre and insoluble NSP were higher for rice bran diet, although the soluble NSP were lower for the rice bran diet.

The effect of dietary treatments on the pig performance is shown in Table 3. Pigs fed the MWB diet supplemented with either the arabinoxylanase $(\mathrm{MWB}+\mathrm{A})$ had a higher feed intake $(\mathrm{P}<0.05)$, higher daily gains $(\mathrm{P}<0.05)$ and better feed utilization $(\mathrm{P}<0.05)$ than pigs fed unsupplemented diet. Additional supplementation of protease (diet MWB+AP) did not improve daily gains or feed utilization, but lowered the feed intake to the MWB diet level. Enzyme treatment did not improved $(\mathrm{P}>0.05)$ the performance of pigs fed the MRB diets and there were no differences $(\mathrm{P}>0.05)$ in performance between pigs fed the MWB diet and MRB without or enzyme supplemented diets.

The effects of dietary treatments on the total fresh faeces excretion, total and ileal endogenous $\mathrm{N}$ excretion is shown in Table 4. Enzyme supplementation reduced $(\mathrm{P}<0.05)$ the fresh faeces and total $\mathrm{N}$ flow $(\mathrm{P}<0.05)$. The endogenous $\mathrm{N}$ flow, calculated according the Centraal Veevoeder Bureau (1998) data based on $\mathrm{N}$-free diet, was less than half of endogenous $\mathrm{N}$ determined in our experiment using EHC diet.

The digestibility of DM, GE, CP, NSP and AA are given in Tables 5 and 6. Pigs fed the MWB diet supplemented with either arabinoxylanase or arabinoxylanase plus protease had a higher $(\mathrm{P}<0.05)$ apparent ileal digestibility of $\mathrm{DM}, \mathrm{GE}$, $\mathrm{CP}$ and apparent and true ileal digestibility of arginine, histidine, isoleucine, lysine and threonine than the pigs fed the other diets. Enzyme supplementation increased $(\mathrm{P}<0.05)$ the ileal digestibility of soluble NSP fractions, however, there were no enzyme effects $(\mathrm{P}>0.05)$ on digestibility of insoluble NSP. The 
TABLE 2

Proximate analysis of maize wheat bran and maize rice bran diets and contents of essential amino acids and non-starch polysaccharide (NSP) contents, g/kg DM

\begin{tabular}{|c|c|c|}
\hline \multirow{2}{*}{ Item } & \multicolumn{2}{|c|}{ Diet } \\
\hline & wheat bran & rice bran \\
\hline Dry mater & 867 & 858 \\
\hline Gross energy, $\mathrm{MJ} / \mathrm{kg}$ & 18.6 & 18.9 \\
\hline Crude fibre & 49.4 & 61.8 \\
\hline Crude fat & 54.2 & 52.4 \\
\hline Crude protein & 221.5 & 213.3 \\
\hline \multicolumn{3}{|l|}{ Amino acids } \\
\hline arginine & 7.7 & 7.6 \\
\hline cystine & 3.8 & 3.6 \\
\hline histidine & 7.5 & 7.7 \\
\hline isoleucine & 11.6 & 11.5 \\
\hline leucine & 20.5 & 19.8 \\
\hline lysine & 12.1 & 12.1 \\
\hline methionine & 3.2 & 3.3 \\
\hline phenylalanine & 12.8 & 12.5 \\
\hline threonine & 7.5 & 7.2 \\
\hline valine & 9.6 & 9.2 \\
\hline \multicolumn{3}{|l|}{ Soluble NSP } \\
\hline rhamnose & 0.2 & 0.1 \\
\hline fucose & 0.2 & 0.1 \\
\hline arabinose & 1.8 & 1.2 \\
\hline xylose & 1.3 & 1.1 \\
\hline mannose & 0.3 & 0.3 \\
\hline galactose & 2.1 & 1.2 \\
\hline glucose & 1.8 & 1.0 \\
\hline total & 7.8 & 5.1 \\
\hline \multicolumn{3}{|l|}{ Insoluble NSP } \\
\hline rhamnose & 0.5 & 0.6 \\
\hline fucose & 2.8 & 3.5 \\
\hline arabinose & 50.0 & 81.6 \\
\hline xylose & 93.0 & 104.8 \\
\hline mannose & 1.6 & 1.8 \\
\hline galactose & 4.1 & 4.7 \\
\hline glucose & 41.4 & 47.0 \\
\hline total & 193.5 & 220.7 \\
\hline
\end{tabular}


TABLE 3

Performance of pigs (10 animal per treatment, 53 d.f) fed the maize-wheat bran-based diet (MWB), that diet supplemented with arabinoxylanase $(\mathrm{MWB}+\mathrm{A})$ or with arabinoxylanase + protease (MWB $+\mathrm{AP})$ and maize-rice bran diet (MRB), that diet supplemented with arabinoxylanase (MWB+A) and arabinoxylanase + protease (MWB $+\mathrm{AP})$

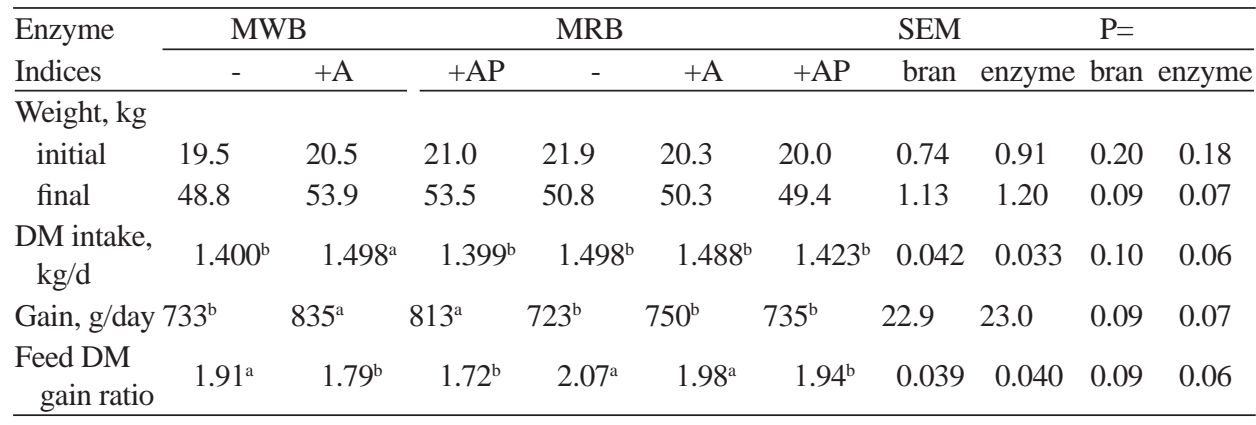

${ }^{a, b}$ means in the same row with different superscripts differ at $\mathrm{P}<0.05$

TABLE 4

Total fresh faeces flow, $\mathrm{g} / \mathrm{kg}$ dry matter intake, (DMI), and total and ileal endogenous nitrogen (N) flows at the distal ileum of the pigs fed fed the maize-wheat bran-based diet (MWB), that diet supplemented with arabinoxylanase (MWB+A) or with arabinoxylanase + protease (MWB +AP) and maize-rice bran $\operatorname{diet}(\mathrm{MRB})$, that diet supplemented with arabinoxylanase $(\mathrm{MWB}+\mathrm{A})$ and arabinoxylanase + protease (MWB +AP)

\begin{tabular}{|c|c|c|c|c|c|c|}
\hline Indices & MWB & $\begin{array}{c}\text { MWB } \\
+\mathrm{A}\end{array}$ & $\begin{array}{c}\text { MWB } \\
+\mathrm{AP}\end{array}$ & MRB & $\begin{array}{l}\text { MRB } \\
+\mathrm{AP}\end{array}$ & SEM \\
\hline Total fresh faeces flow, g/kg DM & $1031^{\mathrm{a}}$ & $983^{\mathrm{b}}$ & $988^{\mathrm{b}}$ & $1053^{\mathrm{a}}$ & $1000^{\mathrm{b}}$ & 8.3 \\
\hline Total N flow, g/kg DM & $8.9^{\mathrm{a}}$ & $7.1^{\mathrm{b}}$ & $7.2^{\mathrm{b}}$ & $9.2^{\mathrm{a}}$ & $8.0^{\mathrm{ab}}$ & 0.21 \\
\hline Ileal endogenous $\mathrm{N}$ flow, $\mathrm{g} / \mathrm{kg} \mathrm{DM}^{1}$ & 4.4 & 4.4 & 4.4 & 4.4 & 4.4 & 0.01 \\
\hline Ileal endogenous $\mathrm{N}$ flow, $\mathrm{g} / \mathrm{kg} \mathrm{DMI}^{2}$ & 2.0 & 2.0 & 2.0 & 2.0 & 2.0 & 0.01 \\
\hline
\end{tabular}

${ }^{1}$ calculated from the enzyme hydrolysed casein diet (EHC)

${ }^{2}$ calculated from the nitrogen free diet, according to CVB (1998)

$\mathrm{a}, \mathrm{b}$ means in the same row with difference superscripts differ at $\mathrm{P}<0.05$

digestibility of DM, GE, CP and AA were not improved $(\mathrm{P}<0.05)$ by addition of arabinoxylanase to the MRB diet. There were no significant differences in total digestibility between the unsupplemented an supplemented MWB and MRB diets.

Value of DE at the ileal (IDE) and total tract (TDE) levels and true ileal digestible $\mathrm{CP}$ and essential AA contents are presented in Table 7. Pigs fed the MWB diet supplemented with either the enzymes A or AP had a higher $(\mathrm{P}<0.05)$ IDE, CP, arginine, histidine, isoleucine, lysine and threonine than the pigs fed other diets. There were no difference $(\mathrm{P}<0.05)$ in $\mathrm{DE}$ and true ileal digestible $\mathrm{CP}$ and $\mathrm{AA}$ contents among the other diets. 
TABLE 5

Apparent ileal and total digestibility (\%) of dry matter, gross energy, crude protein and non-starch polysaccharides (NSP) in pigs fed the maize-wheat bran-based diet (MWB), that diet supplemented with arabinoxylanase $(\mathrm{MWB}+\mathrm{A})$ or with arabinoxylanase + protease $(\mathrm{MWB}+\mathrm{AP})$ and maize-rice bran diet (MRB), that diet supplemented with arabinoxylanase (MWB+A) and arabinoxylanase + protease (MWB +AP)

\begin{tabular}{|c|c|c|c|c|c|c|}
\hline Indicies & MWB & $\mathrm{MWB}+\mathrm{A}$ & $\mathrm{MWB}+\mathrm{AP}$ & MRB & $\mathrm{MRB}+\mathrm{A}$ & SEM \\
\hline \multicolumn{7}{|l|}{ Ileal digestibility } \\
\hline dry matter & $61.0^{\mathrm{b}}$ & $66.8^{\mathrm{a}}$ & $67.0^{\mathrm{a}}$ & $59.9^{\mathrm{b}}$ & $62.3^{\mathrm{ab}}$ & 3.52 \\
\hline energy (GE) & $61.8^{\mathrm{b}}$ & $66.5^{\mathrm{a}}$ & $67.0^{\mathrm{a}}$ & $60.9^{\mathrm{b}}$ & $63.2^{\mathrm{ab}}$ & 2.63 \\
\hline crude protein & $69.2^{\mathrm{b}}$ & $74.3^{\mathrm{a}}$ & $75.2^{\mathrm{a}}$ & $68.2^{\mathrm{b}}$ & $71.8^{\mathrm{ab}}$ & 3.61 \\
\hline \multicolumn{7}{|l|}{ soluble NSP } \\
\hline rhamnose & $16.3^{\mathrm{b}}$ & $24.8^{\mathrm{a}}$ & $25.0^{\mathrm{a}}$ & $17.9^{\mathrm{b}}$ & $23.8^{\mathrm{a}}$ & 3.03 \\
\hline fucose & $14.1^{\mathrm{b}}$ & $19.1^{\mathrm{a}}$ & $20.3^{\mathrm{a}}$ & $15.9^{\mathrm{b}}$ & $21.7^{\mathrm{a}}$ & 2.90 \\
\hline arabinose & $20.3^{\mathrm{b}}$ & $26.3^{\mathrm{a}}$ & $25.9^{\mathrm{a}}$ & $19.8^{\mathrm{b}}$ & $27.8^{a}$ & 3.35 \\
\hline xylose & $15.9^{\mathrm{b}}$ & $20.9^{\mathrm{a}}$ & $21.5^{\mathrm{a}}$ & $16.6^{\mathrm{b}}$ & $22.3^{\mathrm{a}}$ & 3.03 \\
\hline mannose & $14.8^{\mathrm{b}}$ & $20.9^{\mathrm{a}}$ & $22.3^{\mathrm{a}}$ & $15.9^{\mathrm{b}}$ & $25.9^{\mathrm{a}}$ & 3.90 \\
\hline galactose & $17.5^{\mathrm{b}}$ & $23.4^{\mathrm{a}}$ & $22.6^{\mathrm{a}}$ & $16.1^{\mathrm{b}}$ & $24.4^{\mathrm{a}}$ & 2.93 \\
\hline glucose & $22.0^{\mathrm{b}}$ & $28.1^{\mathrm{a}}$ & $29.4^{\mathrm{a}}$ & $23.9^{\mathrm{b}}$ & $30.9^{\mathrm{a}}$ & 3.00 \\
\hline total & $17.2^{\mathrm{b}}$ & $23.0^{\mathrm{a}}$ & $23.9^{\mathrm{a}}$ & $18.5^{\mathrm{b}}$ & $25.5^{\mathrm{a}}$ & 3.52 \\
\hline \multicolumn{7}{|l|}{ insoluble NSP } \\
\hline rhamnose & 11.8 & 13.4 & 12.8 & 13.6 & 14.4 & 2.99 \\
\hline fucose & 10.9 & 12.6 & 12.5 & 12.2 & 13.3 & 3.05 \\
\hline arabinose & 15.5 & 17.0 & 16.3 & 16.5 & 19.8 & 2.09 \\
\hline xylose & 13.3 & 11.5 & 14.9 & 13.0 & 15.4 & 2.98 \\
\hline mannose & 9.9 & 10.3 & 11.8 & 12.4 & 14.1 & 4.34 \\
\hline galactose & 13.3 & 12.2 & 14.5 & 13.5 & 12.0 & 2.22 \\
\hline glucose & 13.4 & 12.5 & 12.8 & 13.3 & 14.0 & 3.00 \\
\hline total & 12.4 & 12.3 & 13.4 & 13.7 & 14.6 & 2.98 \\
\hline \multicolumn{7}{|c|}{ Overall digestibility } \\
\hline dry matter & 73.2 & 75.8 & 76.0 & 73.2 & 75.9 & 3.43 \\
\hline energy & 75.0 & 78.2 & 77.3 & 74.0 & 74.6 & 2.59 \\
\hline crude protein & 80.8 & 81.4 & 82.0 & 81.2 & 81.9 & 3.61 \\
\hline \multicolumn{7}{|l|}{ soluble NSP } \\
\hline rhamnose & 54.5 & 58.6 & 54.8 & 57.3 & 58.3 & 3.30 \\
\hline fucose & 56.6 & 58.8 & 57.9 & 55.9 & 58.8 & 2.98 \\
\hline arabinose & 60.2 & 64.5 & 63.2 & 59.8 & 62.2 & 3.21 \\
\hline xylose & 56.3 & 57.2 & 56.8 & 57.3 & 59.9 & 3.39 \\
\hline mannose & 58.9 & 59.9 & 58.7 & 60.3 & 62.3 & 4.20 \\
\hline galactose & 61.2 & 62.3 & 61.8 & 62.6 & 63.9 & 3.89 \\
\hline glucose & 65.9 & 64.3 & 66.8 & 64.8 & 63.0 & 3.00 \\
\hline total & 59.1 & 61.2 & 62.3 & 59.9 & 61.2 & 3.23 \\
\hline
\end{tabular}


TABLE 5

continued

\begin{tabular}{lcccccc}
\hline Indices & MWB & MWB+A & MWB+AP & MRB & MRB+A & SEM \\
\hline insoluble NSP & & & & & & \\
$\quad$ rhamnose & 30.2 & 32.6 & 29.8 & 31.8 & 33.7 & 3.56 \\
fucose & 26.5 & 26.9 & 27.9 & 28.9 & 30.2 & 3.98 \\
arabinose & 31.6 & 33.0 & 32.8 & 34.0 & 35.0 & 4.03 \\
xylose & 30.6 & 31.6 & 30.2 & 29.9 & 30.5 & 3.89 \\
mannose & 28.8 & 30.6 & 31.0 & 30.5 & 32.9 & 3.00 \\
galactose & 29.9 & 30.2 & 32.5 & 30.0 & 32.5 & 3.26 \\
glucose & 30.3 & 32.6 & 31.8 & 29.7 & 32.6 & 3.80 \\
total & 30.0 & 31.1 & 31.0 & 30.8 & 32.6 & 3.89 \\
\hline
\end{tabular}

${ }^{\mathrm{a}, \mathrm{b}}$ means in the same row with difference superscripts differ at $\mathrm{P}<0.05$

TABLE 6

Ileal apparent and true digestibility (\%) of the essential amino acids in pigs fed the maize-wheat branbased diet (MWB), that diet supplemented with arabinoxylanase (MWB+A) or with arabinoxylanase + protease $(\mathrm{MWB}+\mathrm{AP})$ and maize-rice bran $\operatorname{diet}(\mathrm{MRB})$, that diet supplemented with arabinoxylanase $(\mathrm{MWB}+\mathrm{A})$ and arabinoxylanase + protease $(\mathrm{MWB}+\mathrm{AP})$

\begin{tabular}{|c|c|c|c|c|c|c|}
\hline Indices & MWB & $\mathrm{MWB}+\mathrm{A}$ & $\mathrm{MWB}+\mathrm{AP}$ & MRB & $\mathrm{MRB}+\mathrm{A}$ & SEM \\
\hline \multicolumn{7}{|c|}{ Apparent digestibility } \\
\hline arginine & $75.0^{\mathrm{b}}$ & $80.3^{\mathrm{a}}$ & $81.5^{\mathrm{a}}$ & $73.3^{\mathrm{b}}$ & $75.5^{\mathrm{b}}$ & 0.59 \\
\hline cystine & 73.1 & 75.5 & 74.3 & 72.4 & 74.4 & 0.68 \\
\hline histidine & $70.2^{\mathrm{b}}$ & $75.3^{\mathrm{a}}$ & $75.5^{\mathrm{a}}$ & $69.3^{\mathrm{b}}$ & $71.6^{\mathrm{b}}$ & 0.70 \\
\hline isoleucine & $80.4^{\mathrm{b}}$ & $88.0^{\mathrm{a}}$ & $87.4^{\mathrm{a}}$ & $79.5^{\mathrm{b}}$ & $81.6^{\mathrm{b}}$ & 0.52 \\
\hline leucine & 81.2 & 83.2 & 84.5 & 80.4 & 81.2 & 0.61 \\
\hline lysine & $64.2^{\mathrm{b}}$ & $69.3^{\mathrm{a}}$ & $68.8^{\mathrm{a}}$ & $63.6^{\mathrm{b}}$ & $64.7^{\mathrm{b}}$ & 0.80 \\
\hline methionine & 77.0 & 80.5 & 79.5 & 78.5 & 80.6 & 0.70 \\
\hline phenylalanine & 80.1 & 82.3 & 83.4 & 79.0 & 80.8 & 0.66 \\
\hline threonine & $65.1^{\mathrm{b}}$ & $69.5^{\mathrm{a}}$ & $69.6^{\mathrm{a}}$ & $64.1^{\mathrm{b}}$ & $67.7^{\mathrm{b}}$ & 0.52 \\
\hline valine & 70.3 & 73.6 & 74.0 & 68.4 & 72.5 & 0.97 \\
\hline \multicolumn{7}{|l|}{ True digestibility ${ }^{1}$} \\
\hline crude protein & $87.0^{\mathrm{b}}$ & $92.3^{\mathrm{a}}$ & $93.1^{\mathrm{a}}$ & $86.4^{b}$ & $87.8^{\mathrm{b}}$ & 1.0 \\
\hline arginine & $90.0^{\mathrm{b}}$ & $95.3^{\mathrm{a}}$ & $96.1^{\mathrm{a}}$ & $89.0^{\mathrm{b}}$ & $90.5^{\mathrm{b}}$ & 0.9 \\
\hline cystine & 88.1 & 90.5 & 89.9 & 87.8 & 90.2 & 0.8 \\
\hline histidine & $84.2^{\mathrm{b}}$ & $90.3 \mathrm{a}$ & $90.9^{\mathrm{a}}$ & $83.9^{\mathrm{b}}$ & $86.3^{\mathrm{b}}$ & 0.8 \\
\hline isoleucine & $89.0^{\mathrm{b}}$ & $97.9^{\mathrm{a}}$ & $99.5^{\mathrm{a}}$ & $89.5^{\mathrm{b}}$ & $93.3^{\mathrm{b}}$ & 0.7 \\
\hline leucine & 96.3 & 98.3 & 98.9 & 96.9 & 98.0 & 0.8 \\
\hline lysine & $87.3^{b}$ & $91.8^{\mathrm{a}}$ & $91.3^{\mathrm{a}}$ & $86.6^{\mathrm{b}}$ & $89.1^{\mathrm{ab}}$ & 1.0 \\
\hline methionine & 83.2 & 86.5 & 85.4 & 84.2 & 86.3 & 0.9 \\
\hline phenylalanine & 97.0 & 99.2 & 99.9 & 96.6 & 97.8 & 0.8 \\
\hline threonine & $90.3^{b}$ & $95.4^{\mathrm{a}}$ & $95.3^{\mathrm{a}}$ & $89.3^{\mathrm{b}}$ & $94.0^{\mathrm{ab}}$ & 1.1 \\
\hline valine & 94.8 & 97.0 & 98.2 & 90.6 & 92.9 & 0.9 \\
\hline
\end{tabular}

${ }^{1}$ calculated from the enzyme hydrolysed casein based diet method

$\mathrm{a}, \mathrm{b}$ means in the same row with difference superscripts differ at $\mathrm{P}<0.05$ 
TABLE 7

Value of digestible energy at ileal (IDE, MJ/kg) and total tract level (TDE, MJ/kg) and ileal true digestible of crude protein and the essential amino acids contents ( $\mathrm{g} / \mathrm{kg}$ dry matter ) of the maizewheat bran-based diet (MWB), that diet supplemented with arabinoxylanase (MWB+A) or with arabinoxylanase + protease (MWB + AP) and maize-rice bran diet (MRB), that diet supplemented with arabinoxylanas (MWB+A) and arabinoxylanase + protease (MWB +AP)

\begin{tabular}{lcccccc}
\hline Indices & MWB & MWB+A & MWB+AP & MRB & MRB+A & SEM \\
\hline Digestible energy & & & & & & \\
$\quad$ ileal & $11.5^{\mathrm{b}}$ & $125^{\mathrm{a}}$ & $12.5^{\mathrm{a}}$ & $11.5^{\mathrm{b}}$ & $11.9^{\mathrm{b}}$ & 0.03 \\
total tract & 13.9 & 14.5 & 14.4 & 13.9 & 14.0 & 0.04 \\
& & & & & & \\
Ileal true digestible & & & & & & \\
$\quad$ crude protein & $19.30^{\mathrm{b}}$ & $20.35^{\mathrm{a}}$ & $20.62^{\mathrm{a}}$ & $18.43^{\mathrm{b}}$ & $18.70^{\mathrm{b}}$ & 0.04 \\
arginine & $6.95^{\mathrm{b}}$ & $7.36^{\mathrm{a}}$ & $7.43^{\mathrm{a}}$ & $6.73^{\mathrm{b}}$ & $6.85^{\mathrm{b}}$ & 0.05 \\
cystine & 3.35 & 3.44 & 3.43 & 3.17 & 3.25 & 0.06 \\
histidine & $6.31^{\mathrm{b}}$ & $6.77^{\mathrm{a}}$ & $6.81^{\mathrm{a}}$ & $6.45^{\mathrm{b}}$ & $6.93^{\mathrm{b}}$ & 0.05 \\
isoleucine & $10.37^{\mathrm{b}}$ & $11.4^{\mathrm{a}}$ & $11.60^{\mathrm{a}}$ & $10.33^{\mathrm{b}}$ & $10.76^{\mathrm{b}}$ & 0.05 \\
leucine & 19.77 & 20.18 & 20.30 & 19.20 & 19.42 & 0.06 \\
lysine & $10.57^{\mathrm{b}}$ & $11.11^{\mathrm{a}}$ & $11.06^{\mathrm{a}}$ & $10.50^{\mathrm{b}}$ & $10.80^{\mathrm{b}}$ & 0.04 \\
methionine & 2.69 & 2.79 & 2.76 & 2.75 & 2.81 & 0.07 \\
phenylalanine & 12.42 & 12.70 & 12.79 & 12.05 & 12.20 & 0.06 \\
threonine & $6.77^{\mathrm{b}}$ & $7.15^{\mathrm{a}}$ & $7.13^{\mathrm{a}}$ & $6.45^{\mathrm{b}}$ & $6.79^{\mathrm{b}}$ & 0.04 \\
valine & 9.08 & 9.29 & 9.40 & 8.34 & 8.55 & 0.09 \\
\hline
\end{tabular}

${ }^{a, b}$ means in the same row with difference superscripts differ at $\mathrm{P}<0.05$

The effect of enzyme supplementation on hindgut fermentation of nutrients is shown in Table 8. The hindgut fermentation of CP and soluble NSP, expressed either by subtracting overall from ileal digestibility or as a proportion of undigested material reaching the hindgut, were reduced $(\mathrm{P}<0.05)$ by enzyme supplementation, but the hindgut fermentation of insoluble NSP was not affected by enzyme treatment and there was no difference $(\mathrm{P}<0.05)$ in hindgut fermentation between the MWB diet and the MRB diet.

\section{DISCUSSION}

Although the crude fibre content for the MRB diet was 24\% higher than for the MWB diet, $\mathrm{ADG}$, average daily feed intake (ADFI), F/G, DE and ileal true digestible AA for the MRB diet were similar $(\mathrm{P}=0.08-0.09)$ to those for the MWB diet. This response may be due to an inadequate number of replicates being conducted. Chen (1981) found that there were no differences in feed to gain or DE to gain ratio between rice bran- and wheat bran diets, when both were added at a rate of $20 \%$ into a maizesoyabean meal-based diet for growing-finishing pigs. Yin et al. (1993) reported that 
TABLE 8

Hindgut disappearance (HF, \%) of dry matter, gross energy, crude protein and non-starch polysaccharides (NSP) in pigs fed the maize-wheat bran-based $\operatorname{diet}(\mathrm{MWB})$, that diet supplemented with arabinoxylanase $(\mathrm{MWB}+\mathrm{A})$ or with arabinoxylanase + protease $(\mathrm{MWB}+\mathrm{AP})$ and maize-rice bran diet $(\mathrm{MRB})$, that diet supplemented with arabinoxylanase $(\mathrm{MWB}+\mathrm{A})$ and arabinoxylanase + protease (MWB $+\mathrm{AP})$

\begin{tabular}{|c|c|c|c|c|c|c|}
\hline Indices & MWB & $\mathrm{MWB}+\mathrm{AA}$ & $\mathrm{MWB}+\mathrm{AP}$ & MRB & $\mathrm{MRB}+\mathrm{A}$ & SEM \\
\hline \multicolumn{7}{|c|}{ Hindgut disappearance $^{1}$} \\
\hline energy & $13.2^{\mathrm{a}}$ & $9.0^{\mathrm{b}}$ & $9.0^{\mathrm{b}}$ & $13.1^{\mathrm{a}}$ & $11.4 \mathrm{a}$ & 2.55 \\
\hline crude protein & $11.6^{\mathrm{a}}$ & $7.1^{\mathrm{b}}$ & $6.8^{\mathrm{b}}$ & $13.0^{\mathrm{a}}$ & $9.1^{\mathrm{b}}$ & 1.06 \\
\hline \multicolumn{7}{|l|}{ soluble NSP } \\
\hline rhamnose & $38.2^{\mathrm{a}}$ & $33.8^{\mathrm{b}}$ & $29.8^{\mathrm{b}}$ & $39.4^{\mathrm{a}}$ & $34.5^{\mathrm{b}}$ & 5.63 \\
\hline fucose & $42.5^{\mathrm{b}}$ & $39.7^{\mathrm{b}}$ & $37.6^{\mathrm{b}}$ & $40.0^{\mathrm{b}}$ & $37.1^{\mathrm{b}}$ & 4.89 \\
\hline arabinose & $39.9^{\mathrm{a}}$ & $38.2^{\mathrm{a}}$ & $37.3^{\mathrm{a}}$ & $40.0^{\mathrm{a}}$ & $34.4^{\mathrm{b}}$ & 6.94 \\
\hline xylose & $40.4^{\mathrm{a}}$ & $36.3^{\mathrm{b}}$ & $35.3^{\mathrm{b}}$ & $40.7^{\mathrm{b}}$ & 37.6 & 3.98 \\
\hline mannose & $44.1^{\mathrm{a}}$ & $39.0^{\mathrm{b}}$ & $36.4^{\mathrm{b}}$ & $44.4^{\mathrm{a}}$ & $36.4^{\mathrm{b}}$ & 6.56 \\
\hline galactose & $43.7^{\mathrm{a}}$ & $38.9^{b}$ & $39.2^{\mathrm{b}}$ & $46.5^{\mathrm{a}}$ & $38.0^{\mathrm{b}}$ & 5.98 \\
\hline glucose & $43.9^{\mathrm{a}}$ & $36.2^{\mathrm{b}}$ & $37.4^{\mathrm{b}}$ & $40.9^{\mathrm{a}}$ & $32.1^{\mathrm{b}}$ & 6.89 \\
\hline total & $41.9^{\mathrm{a}}$ & $38.2^{\mathrm{ab}}$ & $38.4^{\mathrm{ab}}$ & $41.4^{\mathrm{a}}$ & $35.7^{\mathrm{b}}$ & 5.84 \\
\hline \multicolumn{7}{|l|}{ insoluble NSP } \\
\hline rhamnose & 18.4 & 19.2 & 17.0 & 18.2 & 19.3 & 5.85 \\
\hline fucose & 15.6 & 14.3 & 15.4 & 16.7 & 16.9 & 6.12 \\
\hline arabinose & 16.1 & 16.0 & 16.5 & 17.5 & 15.2 & 4.89 \\
\hline xylose & 17.3 & 20.1 & 15.3 & 16.9 & 15.1 & 7.45 \\
\hline mannose & 18.9 & 20.3 & 20.6 & 19.2 & 21.3 & 6.00 \\
\hline galactose & 16.6 & 18.0 & 18.2 & 16.5 & 18.2 & 5.89 \\
\hline glucose & 16.9 & 20.1 & 19.0 & 16.4 & 18.8 & 6.02 \\
\hline total & 17.6 & 18.8 & 17.6 & 17.1 & 18.0 & 5.84 \\
\hline \multicolumn{7}{|c|}{ Hindgut disappearance ${ }^{2}$} \\
\hline energy & $34.5^{\mathrm{a}}$ & $26.8^{\mathrm{b}}$ & $27.2^{\mathrm{b}}$ & $33.5^{\mathrm{a}}$ & $30.1^{\mathrm{ab}}$ & 3.89 \\
\hline crude protein & $37.7^{\mathrm{a}}$ & $27.6^{\mathrm{b}}$ & $27.4^{\mathrm{b}}$ & $40.9^{\mathrm{a}}$ & $35.1^{\mathrm{b}}$ & 2.89 \\
\hline \multicolumn{7}{|l|}{ soluble NSP } \\
\hline rhamnose & $45.6^{\mathrm{a}}$ & $44.9^{\mathrm{ab}}$ & $39.7^{\mathrm{b}}$ & $48.0^{\mathrm{a}}$ & $45.2^{\mathrm{a}}$ & 5.02 \\
\hline fucose & 49.5 & 49.0 & 47.1 & 47.8 & 47.0 & 6.03 \\
\hline arabinose & 50.0 & 51.8 & 50.3 & 50.0 & 47.6 & 5.55 \\
\hline xylose & 48.0 & 45.9 & 45.0 & 48.8 & 48.3 & 6.08 \\
\hline mannose & 51.8 & 49.3 & 46.8 & 52.8 & 49.1 & 5.55 \\
\hline galactose & 53.0 & 50.8 & 50.6 & 61.1 & 50.2 & 6.23 \\
\hline glucose & 56.3 & 50.3 & 52.9 & 58.7 & 46.4 & 5.08 \\
\hline total & 50.6 & 49.6 & 50.4 & 50.8 & 47.9 & 4.98 \\
\hline
\end{tabular}


TABLE 8

continued

\begin{tabular}{lllllll}
\hline Indices & MWB & MWB+AA & MWB+AP & MRB & MRB+A & SEM \\
\hline insoluble NSP & & & & & & \\
$\quad$ rhamnose & 20.9 & 22.2 & 23.8 & 21.1 & 22.5 & 5.85 \\
fucose & 17.5 & 16.3 & 17.6 & 19.0 & 18.9 & 6.51 \\
arabinose & 19.0 & 19.3 & 20.8 & 19.8 & 18.9 & 5.55 \\
xylose & 19.9 & 22.7 & 23.6 & 17.5 & 21.8 & 6.08 \\
mannose & 21.0 & 22.3 & 23.4 & 21.9 & 22.7 & 6.66 \\
galactose & 19.1 & 20.5 & 21.3 & 19.1 & 20.7 & 5.45 \\
glucose & 19.5 & 23.0 & 24.1 & 18.9 & 19.9 & 6.48 \\
total & 20.0 & 21.6 & 20.3 & 20.8 & 21.0 & 5.43 \\
\hline
\end{tabular}

a,b means in the same row with difference superscripts differ $(\mathrm{P}<0.05)$

${ }^{1}$ fermentation expressed as the difference between overall and ileal digestibility

2 fermentation expressed as a proportion of undigested material reaching hindgut (=Ferm $1 / 100$ - ileal digestibility)

the nutritional value of rice bran mainly depends on the rice milling procedure. The rice bran used in this trial comes from the rice fine milling process. In this procedure, the outside ring of rice hull was at first dehulled and taken away and the bran come from the second rice milling. The rice bran from the fine milling showed a higher ileal digestibility of crude protein (73\%) and total amino acids (74\%) than rice bran from rough rice milling (56 and 64\%, respectively).

However, both rice bran and wheat bran increase gut fill and also influence other physiological actions such as transit time, nutrient absorption and digestive secretions (Chen, 1979; Graham et al., 1986; Knudsen and Hansen, 1991). Kass et al.(1980) reported that a level of $400 \mathrm{~g} / \mathrm{kg}$ lucerne meal, resulting in a concentration of $311 \mathrm{~g} / \mathrm{kg}$ NDF in the diet for growing pigs, significantly affected the daily gain and feed conversion efficiency compared with the control diet ( $228 \mathrm{~g} / \mathrm{kg}$ of NDF). The average daily gain was reduced from 700 to $520 \mathrm{~g}$ and the feed conversion efficiency increased from 3.23 to 4.91 .

In view of the results reported in the literature (Taverner and Campbell, 1988; Van Lunen and Schulze, 1996; Baidoo et al., 1998; Yin et al., 2000a,b), it was expected that inclusion of enzymes would increase the DE and available AA for the MWB-based diet or MRB-based diet. Since the mechanism of such improvement seems to involve breakdown of the cell wall non-starch polysaccharides (NSP) this would have possible benefits in terms of reducing viscosity, as seen in poultry (Bedford and Classen, 1992; Campbell and Bedford, 1992) and to a lesser extent in pigs (Inborr et al., 1993). Van Lunen and Schulze (1996) found a positive effect of xylanase addition on growth rate and F/G, with an improvement of 9.2 and 5.3\%, respectively, regardless of the level of wheat and maize inclusion in diets for weaned pigs. In the present study, enzyme supplementation only improved the performance 
for the pigs fed the wheat bran, which had higher soluble NSP fractions than the rice bran. Similar to the performance data, the digestibility of nutrients was improved by the enzyme supplementation only with the wheat bran diet. However, enzyme supplementation improved the soluble NSP fraction digestibility for wheat and rice bran diets, although there were no effects on digestibility of insoluble NSP fractions. These results demonstrated that the enzymes used in this study can only breakdown the soluble NSP fractions of the bran as reported by Marquardt et al. (1994). The reason for the no enzyme effect on the performance and digestion in pigs fed the MRB diet may be that there is less scope for enzyme action, since the total soluble NSP in the MRB diet was much lower than that of the MWB diet (4.38 vs $6.76 \mathrm{~g}$ / $\mathrm{kg}$ ). This indicated that the response of enzyme mixture supplementation to wheat bran diet appears to result largely from the functions of arabinoxylanase, rather than protease.

However, it is clear from this study that arabinoxylanase addition has reduced faeces and $\mathrm{N}$ excretion in faeces and shifted part of digestion from the hindgut to the small intestine, which results in less environmental pollutions and less nutrients available for bacterial fermentation in the hindgut. Undigested soluble fibre may exacerbate such diseases as non-specific colitis (Taylor, 1999) and, more recently, Pluske et al. (1996) have shown that soluble fibre may provoke Serpulina hyodysenteriae. Hence, controlling hindgut microbial activity, particularly through nutrimental means, may be of increasing relevance as the use of in-feed antibiotics is more and more constrained.

Recent studies suggest that endogenous gut $\mathrm{N}$ losses are higher than previously estimated and that the differences in apparent digestibility between feedstuffs are attributed to difference in endogenous gut $\mathrm{N}$ losses rather than to differences in true digestibility (Moughan and Rutherfurd, 1990; Marty et al., 1994). Traditionally, the endogenous loss of $\mathrm{N}$ and $\mathrm{AA}$ has been determined following protein free alimentation. This method can be criticised, however, due to the physiologically abnormal nature of the protein free state. There are at least two major potential problems with this approach. First, the rate of whole body protein metabolism will decrease when animals are fed a protein free diet (Moughan and Rutherfurd, 1990) and this may lead to a lowered secretion of proteinaceous material into the gut. In addition to this direct effect of the protein-deplete metabolic state, the absence of stimulation from dietary peptides or protein, per se, may lead to a reduced secretion of protein into the gut. The present study with the EHC method confirmed these conclusion and therefore it would be useful to determine ileal endogenous AA follow with the EHC method for correcting the apparent ileal digestibility of AA to true ones.

In summary, it can be concluded that the rice and wheat bran used in this study have the similar feeding values for growing pigs. The soluble NSP in the wheat and rice bran diet can be partly hydrolysed in the gastro-intestinal tract of pigs by arabinoxylanase supplementation of feeds. 


\section{REFERENCES}

AOAC, 1990. Official Methods of Analysis, Association of Official Analytical Chemists. $10^{\text {th }}$ Edition. Washington, DC

Bedford M.R., Classen H.L., 1992a. Reduction of intestinal viscosity through manipulation of dietary rye and pentosanase concentration is effected through changes in the carbohydrates composition of intestinal aqueous phase and results in improved growth rate and food conversion efficiency. J. Nutr. 122, 560-569

Baidoo S.K., Liu Y.G., Yungblut D., 1998. Effect of microbial enzyme supplementation on energy, amino acid digestibility and performance of pigs fed hulless barley for swine. Can. J. Anim. Sci .78,202-210

Campbell G.L., Bedford M.R., 1992. Enzyme applications for monogastric feeds: A review. Can. J. Anim. Sci. 72, 449-466

Chen Y.F., 1979. Faecal digestibility of rice bran and wheat bran. Feedstuff Res. 3, 12-16

Chen Y.F., 1981. Evaluation of rice bran as feedstuffs for pigs. Feedstuff Res. 5, 65-79

CVB, 1998. Nutritive Value of Feed Ingredients. Centraal Veevoeder Bureau, Postbus 2176, 8203 AD Lelystad (The Netherlands)

De Lange C.F.M., Sauer W.C., Mosenthin R., Souffrant W.B., 1989. The effect of feeding different protein-free diets on the recovery and amino acid composition of endogenous protein collected from distal ileum and feces in pigs. J. Anim. Sci. 67, 746-754

Dierick N., Vervaeke I.L., Demeyer D.I., Decuypere J., 1989. Approach to the energetic importance of fibre digestion in pigs. 1. Importance of fermentation in the overall energy supply. Anim. Feed Sci. Tech. 23,141-168

Englyst H.N., Hudson G.J., 1996. The classification and measurement of dietary carbohydrates. Food Chem. 57,15-21

Fenton T.W., Fenton M., 1979. An improved procedure for the determination of chromic oxide in feed and feces. Can. J. Anim. Sci. 59, 631-634

Graham H., Hesselman K., Jogsson E., Åman P., 1986 The influence of wheat bran and sugar beet pulp on the digestibility of dietary components in a cereal-based pig diet. J. Nutr. 116, 242-251

Hanrahan T.J., O'Grady J.F., 1970. Pollard as an energy source in the diet of growing-finishing pigs. Irish J. Agr. Res. 44, 133-135

Inborr J., Schmitz H., Ahrene F., 1993. Effect of adding fibre and starch degrading enzymes to a barley/wheat based diet on performance and nutrient digestibility in different segments of the small intestine of early weaned pigs. Anim. Feed Sci. Tech. 44, 113-127

Kass L.M., Van Soest P.J., Pond W.G., Lewis B., McDowell R.E., 1980. Utilization of dietary fibre from alfalfa by growing swine. J. Anim. Sci. 50, 175-191

Knudsen K.E.B., Hansen I., 1991. Gastrointestinal implications in pigs of wheat and oat fractions. 1. Digestibility and bulking properties of polysaccharides and other major constituents. Brit. J. Nutr. 65, 217-232

Marquardt R.R., Boros P., Guenter W., Crow G., 1994. The nutritive value of barley, rye, wheat and corn for young chicks as affected by use of a Trichoderma Reesei enzyme preparation. Anim. Feed Sci. Tech. 45, 363-378

McClean D., 1993. Effects of processing of raw materials on digestibility of diets for weaned pigs. $\mathrm{PhD}$. Thesis, The Queen's University of Belfast

Marty B.J., Chavez E.R., de Lange C.F.M., 1994. Recovery of amino acids at the distal ileum for determining apparent and true ileal amino acid digestibilities in growing pigs fed various heatprocessed full-fat soybean products. J. Anim. Sci. 72, 2029-2037 
Moughan P.J., Rutherfurd S.M., 1990. Endogenous flow of total lysine and other amino acids at the distal ileum of the protein or peptide fed rat: The chemical labelling of gelatin protein by transformation of lysine to homoarginine. J. Sci. Food Agr. 52, 179-192

NRC, 1998. Nutrient Requirements of Swine. $10^{\text {th }}$ Edition. National Academy Press, Washington, DC

Pluske J.R., Siba P.M., Pethick D.W., Durmic Z., Mullan B.P., Hampson D.J., 1996. The incidence of swine dysentery in pigs can be reduced by feeding diets that limit the amount of fermentable substrate entering the large intestine. J. Nutr. 126, 2920-2933

SAS Institute Inc., 1988. SAS User's guide Version 6.03. SAS Institute, Inc., Cary, NC

Sauer W.C., 1983. A modified nylon bag technique for determining the apparent protein digestibility in feedstuffs of pigs. Can. J. Anim. Sci. 62, 233-237

Taverner M.R., Campbell R.G., 1988. The effects of protected dietary enzymes on nutrient absorption in pigs. In: L. Buraczewska, S. Buraczewski, B. Pastuszewska, T. Żebrowska (Editors). Proceedings of $4^{\text {th }}$ International Symposium on Digestive Physiology in Pigs. Polish Academy of Sciences, Jabłonna (Poland), pp. 357-359

Taylor D.J., 1999. In: Pig Diseases. $5^{\text {th }}$ Edition. Burlington Press, Cambridge (UK), pp. 271-296

Van Lunen T.A., Schulze H., 1996. Influence of Trichoderma longibrachiatum xylanase supplementation of wheat and corn based diets on growth performance of pigs. Can. J. Anim. Sci. 76, 271-273

Yin Y.L., McEvoy J.D.G., Schulze H., Hennig U., Souffrant W.B., McCracken K.J., 2000a. Apparent digestibility (ileal and overall) of nutrients and endogenous nitrogen losses in growing pigs fed wheat or its by-products without or with xylanase supplementation. Livest. Prod. Sci. $62,119-132$

Yin Y.L., McEvoy J.D.G., Schulze H., McCracken K.J., 2000b. Studies on cannulation method and alternative indigestible marker and the effects of food enzyme supplementation in barley-based diets on ileal and overall apparent digestibility in growing pigs. Anim. Sci. 70, 63-72

Yin Y.L., Baidoo S.K., Boychuk J.L.L., 2000c. Effects of enzyme supplementation on the performance of broiler fed corn, wheat, barley or micronization barley diets. J. Anim. Feed Sci. 9, 493-504

Yin Y.L., Baidoo S.K., Schulze H., Simmins P.H., 2001a. Effects of supplementation of diets containing hulless barley varieties having different level of non-starch polysaccharides with $\beta$-glucanase and xylanase on the physiological status of the gastrointestinal tract and nutrient digestibility of weaned pigs. Livest. Prod. Sci. 71, 97-107

Yin Y.L., Baidoo S.K., Liu K.Y.G., Schulze H., Simmins P.H., Jin L.Z., 2001b.The effects of different carbohydrase and protease supplementation on apparent (ileal and total-tract) digestibility of nutrients of five hulless barley in young pigs. Livest. Prod. Sci. 71, 109-120

Yin Y.-L., Huang R.-L., Zhong H.-Y., Li T.J., Souffrant W.B., de Lange C.F.M., 2002a. Evaluation of mobile bag technique for determining apparent ileal digestibilities of protein and amino acids in growing pigs. J. Anim. Sci. 80, 409-420

Yin Y.-L., Gurung Nar K., Jeaurond E.A., Sharpe P.H., de Lange C.F.M., 2002b. Nutrient digestibility of Canadian-developed sorghum and pearl millet grains fed to growing pigs compared to traditional cereal grains. Can. J. Anim. Sci. 82,385-391

Yin Y.-L., Zhong H.-Y., Huang R.-L., Chen C.-M., Li T.-J., Pai Y.-F., 1993. Nutritive value of feedstuffs and diets for pigs. I. Chemical composition, apparent ileal and fecal digestibility. Anim. Feed Sci. Tech. 44, 1-27 


\section{STRESZCZENIE}

\section{Wpływ dodatku arabinoksylanazy i proteazy na wartość pokarmową diet zawierających otręby pszenne lub ryżowe w żywieniu rosnących świń}

Przeprowadzono dwa doświadczenia, jedno strawnościowe i jedno wzrostowe, celem zbadania wpływu dodatku enzymów paszowych: arabinoksylanazy lub arabinoksylanazy z proteaza, na strawność składników pokarmowych, przepływ azotu oraz wyniki produkcyjne rosnących świń. Doświadczenie strawnościowe w układzie kwadratu łacińskiego $6 \times 6$, przeprowadzono na 6 knurkach mieszańcach (landrasa $\times$ wielka biała $\times$ chińska czarna), o początkowej m.c. około $20 \mathrm{~kg}$, z kaniulami typu T w końcu jelita biodrowego; oznaczono w nim strawność i przepływ azotu. Zastosowano 6 następujących diet: 1. kukurydza + otręby pszenne (MWB); 2. MWB plus arabinoksylanaza (A); 3. MWB plus arabinoksylanaza i proteaza (AP); 4. kukurydza + otręby ryżowe (MRB); 5. MRB + arabinoksylanaza A; 6. MRB + arabinoksylanaza i proteaza (AP). Dieta MWB zawierała rozpuszczalne nieskrobiowe polisacharydy (NSP), 0,8\%, nierozpuszczalne NSP, $19 \%$, białka ogólnego 22\%, oraz 18,6 MJ/kg energii brutto (EB), dawka MRB - odpowiednio: 0,5; 22; 21 oraz 18,9 MJ EB. W doświadczeniu wzrostowym 30 maciorek i 30 wieprzków, o początkowej masie ciała 20,5 $\pm 0,76 \mathrm{~kg}$, podzielono losowo na 6 grup (po 5 maciorek i 5 wieprzków w każdej) i żywiono do woli takimi samymi dietami jak w doświadczeniu strawnościowym.

Nie stwierdzono istotnych różnic w średnich dziennych przyrostach $(\mathrm{P}=0,09)$, wykorzystaniu paszy $(\mathrm{P}=0,09)$, jelitowej strawności składników pokarmowych $(\mathrm{P}=0,09)$ i przepływie azotu $(\mathrm{P}>0,08)$ u świń otrzymujących diety MWB i MRB, chociaż zawartość włókna surowego w diecie MRB była większa o 9,7 g/kg niż w diecie MWB. Pobranie s.m. diety MWB zwiększyło się $(\mathrm{P}<0,05)$ po uzupełnieniu jej enzymem A. Dodatek do diety MWB zarówno arabinoksylanazy jak i arabinoksylanazy z proteazą poprawił średnie dzienne przyrosty i wykorzystanie paszy $(\mathrm{P}<0,05)$. Wydzielanie $\mathrm{N}$ endogennego, oznaczone $\mathrm{w}$ jelicie biodrowym przy skarmianiu diety z enzymatycznie hydrolizowaną kazeiną, było o połowę większe niż obliczone przy zastosowaniu diety bezbiałkowej. Jelitowa strawność rozpuszczalnych NSP diet MWB i MRB była istotnie większa $(\mathrm{P}<0,05)$ po uzupełnieniu dawek enzymami: arabinoksylanazą oraz arabinoksylanazą i proteazą. Nie stwierdzono wpływu dodatku enzymów na strawność nierozpuszczalnych NSP.

Otrzymane wyniki sugerują, że enzymy rozkładające NSP zmniejszają głównie negatywny antyodżywczy wpływ rozpuszczalnych NSP w jelicie cienkim rosnących świń. 